\title{
Development parameters of the latent period as a response of rubber tree resistance to South American leaf blight
}



${ }^{1}$ UNESP - Univ Estadual Paulista, School of Agriculture. 1780, Dr. José Barbosa de Barro St. Lageado Experimental Farm. PO Box $18610-307$ Botucatu - São Paulo State - Brazil. ${ }^{2}$ UNESP - Univ Estadual Paulista, Institute of Biosciences of Botucatu. 250, Prof. Dr. Antônio Celso Wagner Zanin St. Rubião Junior District, PO Box 18618-689 - Botucatu - São Paulo State - Brazil.

E-mail: João Alberto Zago Bevenuto(jbevenuto@yahoo.com.br)

Data de chegada: 29/11/2018. Aceito para publicação em: 26/03/2021.

$10.1590 / 0100-5405 / 217084$

\section{ABSTRACT}

Bevenuto, J.A.Z.; Passos, J.R.S.; Furtado, E.L. Development parameters of the latent period as a response of rubber tree resistance to South Smerican leaf blight. Summa Phytopathologica, v.47, n.2, p.103-109, 2021.

The major phytosanitary problem for rubber tree cultivation in Brazil is the disease known as South American leaf blight, caused by the fungus Microcyclus ulei. Its symptoms manifest in young leaves and cause intense defoliation, resulting in reduced latex production and even the death of susceptible plants. Thus, this disease consists in a constant threat to East Asian plantations. As worldwide traditional breeding programs have evolved, interspecific hybrid clones have currently been used for planting. They are more productive and show better resistance to pathogens. However, traditional breeding programs have not led to significant progress in resistance to South American leaf blight since the selection is directed to clones with complete resistance. In this pathosystem, horizontal or partial resistance (HR) and vertical or complete resistance (VR) can act simultaneously, evidencing their complexity and difficult quantification. This study aimed to: characterize the foliar lesion type in Hevea sp. X M. ulei pathosystem; verify the clonal susceptibility to pathogens; analyze the infection frequency for resistance quantification in Hevea sp. x M. ulei pathosystem, and recommend differentiating rubber tree clones to quantify $M$. ulei races in Brazil. The monocyclic parameters (latent period and lesion diameter) are applicable for resistance quantification in Hevea sp. x M. ulei pathosystem. Latent period had slight variation among clones. Lesion diameter had wide variation among clones and was a discriminating parameter for horizontal resistance and vertical resistance.

Keywords: epidemiological modeling, latent period, horizontal resistance, vertical resistance, Hevea sp., Microcyclus ulei.

\section{RESUMO}

Bevenuto, J.A.Z.; Passos, J.R.S.; Furtado, E.L. Parâmetros do desenvolvimento do período latente em resposta à resistência da seringueira ao mal das folhas. Summa Phytopathologica, v.47, n.2, p.103-109, 2021.

O maior problema fitossanitário na heveicultura Brasileira é a doença conhecida por mal das folhas causada pelo fungo Microcyclus ulei. Cujos sintomas ocorrem nas folhas jovens, causando intensas desfolhas, diminuindo a produção de látex e até mesmo a morte em plantas suscetíveis. Consistindo assim em uma ameaça constante aos plantios do Oriente Asiático. Com a evolução dos programas de melhoramento mundial genético tradicional, atualmente são utilizados para plantio, clones híbridos interespecíficos. Os quais são mais produtivos e apresentam melhor resistência aos patógenos. No entanto, através dos programas de melhoramento genético tradicional, não houve progresso significativo quanto à resistência ao mal das folhas, devido à seleção serem dirigidas para clones com resistência completa. Neste patossistema a resistência horizontal (RH) ou resistência parcial e resistência vertical (RV) ou resistência completa, podem agir simultaneamente, sendo complexas e de difícil quantificação. Este trabalho teve como objetivo caracterizar o tipo de lesão foliar do patossistema Hevea sp. x $M$. ulei, verificar a suscetibilidade clonal aos patógenos, analisar a frequência de infecção visando quantificar a resistência no patossistema Hevea sp. x M. ulei e sugerir clones diferenciadores de seringueira além de quantificar as raças de $M$. ulei no Brasil. Os parâmetros monocíclicos (período latente e diâmetro de lesão) são aplicáveis na quantificação de resistência no patossistema Hevea sp. x M. ulei. O período de latência teve pouca variação entre os clones. O diâmetro de lesão teve variação ampla entre os clones, sendo um parâmetro discriminante para a resistência horizontal e resistência vertical.

Palavras-chave: modelagem epidemiológica, período latente, resistência horizontal, resistencia vertical, Hevea sp., Microcyclus ulei.

The rubber tree, Hevea brasiliensis, which belongs to the family Euphorbiaceae, is a forest species that originated in the Amazon region and has great economic importance, especially for constituting the major source of natural rubber in Brazil and worldwide (9).

Although the Brazilian Amazon region is its center of origin, the rubber tree has shown high adaptability to the most varied environments (10). It was introduced in Eastern countries (Sri Lanka, Singapore and Malaysia) at the beginning of the 1900s. The climate in those regions is highly similar to that in Brazil, but the disease South American leaf blight is absent due to the absence of the pathogen, resulting in good development and high yields. Currently, more than $90 \%$ of the world's rubber production originates in those countries (8).
Brazilian production in 2020 corresponded to approximately $1 \%$ of the world's volume of natural rubber, totaling 362 thousand tons of yield in a planted area of 158 thousand ha (11). In Brazil, São Paulo State is the first producer of natural rubber, generating approximately 242 thousand tons of coagulated latex (11). Application of latex is wide and involves hospitals, pharmaceuticals, toys, shoes, civil construction, agriculture, industry and automotive parts (22), including pneumatic tires, which consume around $70 \%$ of the rubber produced in the world.

Its reduced participation in the global market is due to several factors like: production system based on extractivism and not on commercial exploration; occurrence of South American leaf blight, caused by the fungus Microcyclus ulei (anamorph: Pseudocercospora 
ulei); agronomic aspects, e.g., high tapping frequency, and employed types (8). Greater defoliation, of around $75 \%$, can reduce latex production by up to $50 \%$ (5).

It must be highlighted that Brazil also imports natural rubber; in 2017, Brazilian importations totaled approximately 406 million dollars for around 225 thousand tons of natural rubber (14).

Strategies to address this problem are directed to generating and planting productive cultivars resistant to the pathogen. In genetic breeding, resistance against pathogens is generally associated with lesion size, reduced sporulation and latent period of the fungus on leaves. Determination of latent periods and sporulation is highly employed for horizontal resistance $(2,18,20,23)$.

As traditional breeding programs evolved, interspecific hybrid clones have been employed since they are more productive and show better resistance to pathogens $(19,21)$. However, as the fungus has high adaptation capacity, symptoms of the disease have already been found in clonal gardens and greenhouses.

The extensive genetic variability for resistance to South American leaf blight allows the use of clones, progenies or resistant species in the management of this disease $(1,6,17)$.

Leaf blight symptoms can be seen on young leaves and stems, as well as on flowers and fruits. Injured areas present small circular necrotic patches and black spots constituted of fruiting organs of the fungus and exhibit sandpaper aspect (7).

Symptoms first manifest in young leaves and are more visible within 5-6 days after penetration of the fungus; green spots formed by a spore mass appear on the abaxial side. As the infection process progresses, the leaflets wrinkle, presenting aspect of burnt and fall. Infected leaves that are young but older than two weeks do not fall, subsequently receiving structures produced by the fungus and named stroma. Susceptible terminal buds dry due to successive defoliation, leading to the onset of plant descending to death $(7,8)$.

The present study aimed to characterize the foliar lesion type, verify the clonal susceptibility, and analyze the infection frequency using 23 rubber tree clones and $6 \mathrm{M}$. ulei isolates for resistance quantification in Hevea sp. x M. ulei pathosystem, as well as to recommend for planting the rubber tree clones that presented greater resistance to South America leaf blight.

\section{MATERIAL AND METHODS}

The fungal isolates used in this study were obtained from "Umuarama" Farm, Registro Municipality/São Paulo State, Brazil, which is located at $24^{\circ} 24^{\prime} 14.00^{\prime} \mathrm{S}$ and $47^{\circ} 48^{\prime} 16.47^{\prime \prime} \mathrm{W}$, in the region known as "Vale do Ribeira", where mean altitude is $52 \mathrm{~m}$, annual mean rainfall is $1627 \mathrm{~mm}$ and annual mean temperature is $22^{\circ} \mathrm{C}$. Rubber plants were found in a definitive plantation in monoclonal blocks dispersed throughout the farm.

According to the method described by Junqueira et al. (13), individual samples of the fungus $M$. ulei were collected from corinaceous lesions on the leaves of rubber trees and placed in a test tube containing PDA medium (potato dextrose agar). Small colonies were obtained and ground on the edge of tubes with a glass rod and 5 $\mathrm{mL}$ sterile distilled water; the product was placed in 125-ml Erlenmeyer flasks containing $20 \mathrm{ml}$ neopeptone, sucrose and agar each, and the produced inoculum was distributed on the agar surface followed by incubation at $24^{\circ} \mathrm{C} \pm 1{ }^{\circ} \mathrm{C}$ in a dark room. After 15 days, $12 \mathrm{~h} / 12 \mathrm{~h}$ photoperiod was set during 2 to 3 days for inoculum preparation. The inoculum was obtained by adding $10 \mathrm{ml}$ sterile distilled water per Erlenmeyer, and the colonies were prepared with a brush.

Inoculations were done by spraying a conidial suspension on the abaxial surface of 6-to-8-day-old leaflets, corresponding to stages B1 and B2, described by Hallé et al. (12); conidia were obtained from six fungal cultures at "Umuarama" Farm, in "Vale do Ribeira". The concentration of these spores varied with the age of the culture $\left(2 \times 10^{5}\right.$ for 10-to-12-day-old cultures; $3 \times 10^{5}$ for 12-to-16-day-old cultures; and $5 \times 10^{5}$ for older cultures), which were kept in medium with neopeptone, sucrose and agar, according to the methodology proposed by Junqueira et al. (13). Each isolate was inoculated at least three times in emerging leaves.

The employed rubber cultivars (Table 1) were grafted onto genetically heterogeneous rootstocks cultivated in plastic bags containing $10 \mathrm{~kg}$ substrate with $30 \%$ tanned manure to $70 \%$ soil. Seedlings were in third-leaf emergence and were kept in a greenhouse belonging to the former National Center for Rubber Tree and Dendê Research, currently named Support Nuclei for Research and Technology Transference (NAPT), Eastern Amazon EMBRAPA.

Table 1. Rubber tree clones used for resistance monocyclic parameter tests and kept in a greenhouse at Eastern Amazon EMBRAPA in 1990.

\begin{tabular}{cccccc}
\hline \multicolumn{5}{c}{ Rubber tree clones } \\
\hline CNSAM 7665 & Fx 3844 & Fx 4098 & IAN 2909 & IAN 7002 & MDF 180 \\
F 4542 & Fx 3864 & Fx 985 & IAN 3087 & IAN 713 & PB 86 \\
Fx 2261 & Fx 3899 & GT 1 & IAN 6158 & IAN 717 & RRIM 600 \\
Fx 2804 & Fx 3925 & IAN 2388 & IAN 6323 & IAN 873 & \\
\hline
\end{tabular}

Following inoculation, plants were stored in a humid chamber $(97 \% \mathrm{RH})$, at $24^{\circ} \mathrm{C}$, alternate photoperiod $(12 \mathrm{~h})$. Then, they were removed from the humid chamber, kept for eight days in growing chambers at $24^{\circ} \mathrm{C}$ and $80 \%-85 \% \mathrm{RH}$, and finally transferred to the greenhouse at $26-30^{\circ} \mathrm{C}$ and $78 \%-83 \% \mathrm{RH}$.

Evaluations were done to determine the latent period (18). At the $15^{\text {th }}$ day after inoculation, the number of lesions was obtained for every $8 \mathrm{~cm}^{2}$ leaf surface, the mean diameter of lesions was determined and the sporulation intensity was verified. As shown in Table 2, lesions were classified based on a score scale and on the reactions of each type (13), adopting score zero for leaves without spores and score one for leaves with spores.

For statistical analysis of the lesion size $\left(\mathrm{mm}^{2}\right)$ and latent period (days) of inoculated seedlings, a generalized linear model with gamma probability distribution and the logit link function were used $(4,16)$, considering the factors clones and isolates. The goodness of fit of the model was assessed based on analysis of deviance. For eventual double interaction, a given factor was studied within the levels of the other factor. The Tukey-Kramer Test was adopted to compare treatments (25), using proc genmod (SAS - Free Statistical Software, SAS University Edition).

According to the method described by Vanderplank (24), vertical resistance (VR) and horizontal resistance (HR) of each clone were quantified based on the differences between reactions, on the isolate that was most adapted to the clone and on the mean of the remaining isolates, using monocyclic parameters. 
Table 2. Classification of lesions (adapted score), according to number of spores, lesion size and score scale (13).

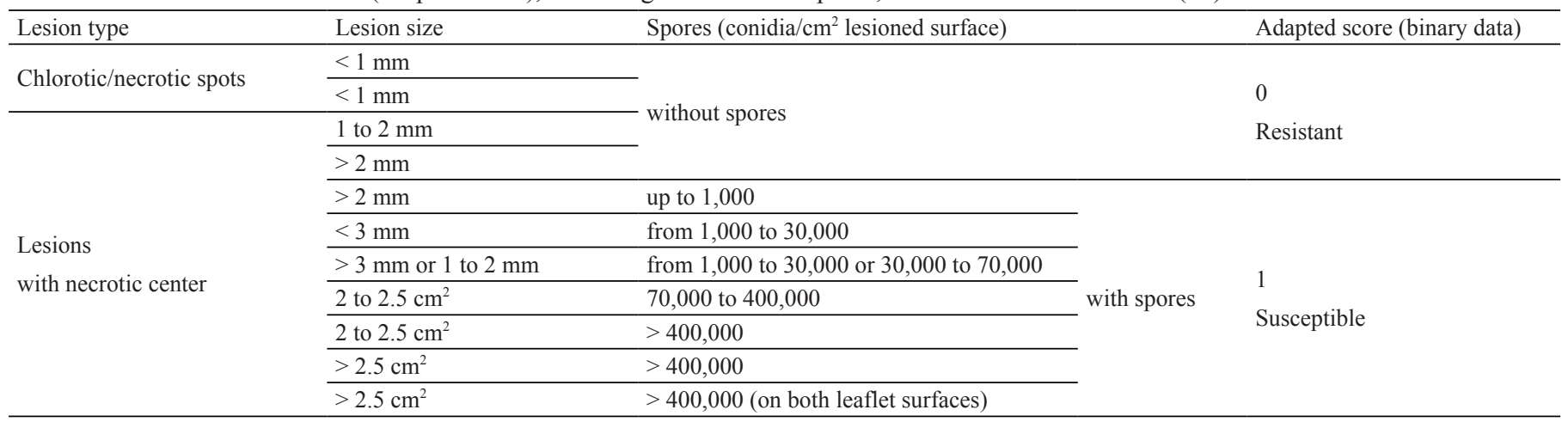

Source: Adapted from Junqueira et al. (13).

Table 3. Mean values of foliar lesion size caused by the pathogen $\left(\mathrm{mm}^{2}\right)$ and standard deviation in parentheses, according to the clone of rubber tree (Hevea ssp.) and the isolate of the fungus South American leaf blight (Microcyclus ulei).

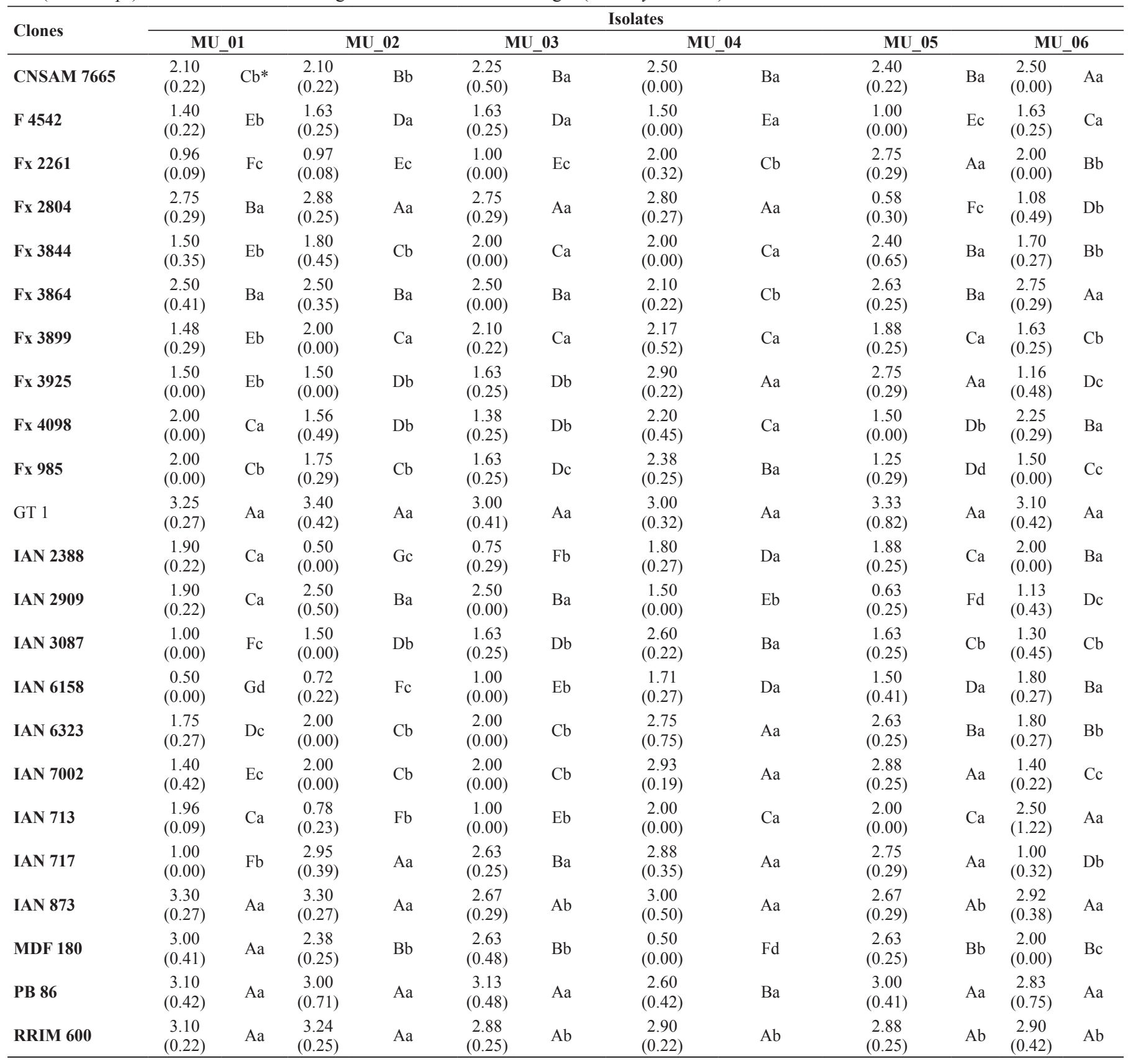

*Means followed by the same uppercase letter in the column and lowercase letter on the line do no differ statistically according to LSM test (p<0.05). 


\section{RESULTS AND DISCUSSION}

All six analyzed M. ulei isolates were obtained from "Umuarama" Farm; they were named MU_01, MU_02, MU_03, MU_04, MU_05 and MU_06.

The variable lesion size had good fit to the generalized linear model (deviance per degree of freedom=1.27), presenting significant effects on the major factors (clone and isolate) and on the interaction, both at $\mathrm{p}<0.0001$.

As show in Table 3, for isolate MU_01, the most susceptible clones (greatest mean lesioned area) were: GT 1, IAN 873, MDF 180, PB 86 and RRIM 600; on the other hand, greatest resistance (smallest mean lesioned area) was obtained for the clone IAN 6158. For isolate MU 02, the most susceptible clones were: Fx 2804, GT 1, IAN 717, IAN 873, PB 86 and RRIM 600, while the most resistant clone was IAN 2388. For isolate MU_03, the most susceptible clones were: Fx 2804, GT 1, IAN 873, PB 86 and RRIM 600, and the most resistant clone was IAN 2388. For isolate MU_04, the most susceptible clones were: Fx 2804, Fx 3925, GT 1, IAN 6323, IAN 7002, IAN 717, IAN873 and RRIM 600, and the clone of greatest resistance was MDF 180. For isolate MU_05, the most susceptible clones were: Fx 2261, Fx 3925, GT 1, IAN 7002, IAN 717, IAN 873, PB 86 and RRIM 600, while the clones of greatest resistance were: Fx 2804 and IAN 2909. For isolate MU_06, the most susceptible clones were: CNSAM 7665, Fx 3864, GT 1, IAN 713, IAN 873, PB 86 and RRIM 600, and the most resistant clones were: Fx 2804, Fx 3925, IAN 2909 and IAN 717.

Considering the comparisons within each clone, Fx 2804, IAN 717, Fx 3925 and MDF 180 are highlighted for presenting alternate patterns of resistance and susceptibility to different isolates, while GT 1, IAN 873 and RRIM 600 showed only susceptibility patterns to all isolates.

The variable latent period had good fit to the generalized linear model (deviances per degree of freedom=1.59), showing significant effects on the major factors (clone and isolate) and on the interaction, both at $\mathrm{p}<0.0001$.

Specific resistance (empty cells) (Table 4) is resistance expressed against certain races causing South American leaf blight, i.e., the clone has resistance against the pathogen or is susceptible, which is named vertical resistance and is an excellent parameter to differentiate between races (23). Therefore, there are 5 physiological races originated in and adapted from the region "Vale do Ribeira", while isolates MU_02 and MU 03 are the same races of M. ulei (3).

Considering the latent period for isolate MU_01, the most susceptible clones (shortest latent period) were: GT 1, IAN 873, PB 86 and RRIM 600, and those of greatest resistance (longest latent period) were: Fx 2261, Fx 2804, Fx 4098 and IAN 2388. For isolate MU_02, the most susceptible clones were: Fx 2804, GT 1, IAN 717 and PB 86, and those of greatest resistance were: Fx 2261, Fx 4098 and MDF 180. For isolate MU_03, the most susceptible clones were: Fx 2804, GT 1, IAN 717, PB 86 and RRIM 600, and those of greatest resistance were: Fx 2261, Fx 4098 and MDF 180. For isolate MU_04, the most susceptible clone was PB 86, and that of greatest resistance was Fx 4098. For isolate MU_05, the most susceptible clones were: Fx 3844, Fx 3864, Fx 3899, IAN 7002 and MDF 180, and that of greatest resistance was CNSAM 7665. For isolate MU_06, the most susceptible clones were: IAN 873 and RRIM 600, and those of greatest resistance were: CNSAM 7665, Fx 985, IAN 2388 and IAN 6158.

Analyzing the comparisons within each clone, Fx 2804 and MDF 180 were highlighted for presenting alternate patterns of resistance and susceptibility to different isolates, while GT 1, PB 86 and RRIM 600 showed only susceptibility patterns for most isolates, and the clones that had the greatest resistance to isolates were: CNSAM 7665, Fx 2261, Fx 4098, Fx 985 and IAN 2388.

Comparison between the mean values of lesion size (Table 3 ) and the mean values of latent period (Table 4) indicated that the smaller the lesion diameter, the longer the latent period, which may lead to complete resistance. However, exceptions were the clones CNSAM 7665, Fx 985 and Fx 4098, which did not have the smallest lesion sizes, but had a good latent period.

As shown in Tables 3 and 4, the clones Fx 3864, Fx 3844, Fx 3899, GT 1, IAN 713, IAN 873, IAN 6323, IAN 7002, PB 86 and RRIM 600 had either susceptibility to isolates from lesions caused by South American leaf blight or shorter latent period. The rubber tree clones Fx 985, Fx 4098, IAN 2388, IAN 2909 and IAN 6158 were most resistant to $M$. ulei isolates considering lesion size or latent period.

Vertical resistance (VR) and horizontal resistance (HR) were quantified based on the differences among the reactions of the most aggressive inoculum, the greatest lesion diameter and the shortest latent period, as well as on the mean of the remaining isolates, as shown in Figures 1 and 2 (19).

F 4542, extensively used as the parental for a large number of clones employed in Brazil, especially in the period of PROBOR I and II (financial support programs for the planting of rubber trees in the 1970s), as well as IAN 717, Fx 3864 and Fx 3899, presented high HR to the studied pathogen, followed by the clones CNSAM 7665, IAN 2388 and IAN 6158, based on the latent period (Figure 2). However, considering all M. ulei $x$ Hevea $s p$. interactions for the latent period, HR was greater, while VR was incomplete.

These data repeat for lesion diameter, except considering CNSAM 7665. The clone Fx 2261 had 50\% VR and HR. In "Vale do Ribeira"/ São Paulo State, which has low disease occurrence pressure, Fx 2261 is considered promising, while in Bahia, where there is greater disease occurrence pressure, this clone is highly attacked and not recommended.

In the Hevea sp. x M. ulei pathosystem, greater participation of HR is confirmed, demonstrating that when VR is overcome by the pathogen, the rubber tree remains alive, producing latex by means of HR, which is therefore closely correlated to the tolerance capacity of the rubber tree when the latter is affected by South American leaf blight.

Horizontal resistance can be associated with another defense mechanism, avoidance (15), since when M. ulei overcomes the defense barriers and starts producing spores, the only still intact and active resistance is HR, allowing the rubber tree to make leaf exchanges and preventing the disease from establishing and causing greater losses.

Another important factor is that no clone reached VR and HR in a latent period longer than 9 days, alerting for possible attacks by M. ulei to a rubber tree within 21 days after leaf emergence, which evidences that this pathogen is aggressive and that a longer latent period could provide better resistance to the disease. 
Table 4. Mean values of latent period (days) and standard deviation in parentheses, according to the clone of rubber tree (Hevea ssp.) and the isolate of the fungus South American leaf blight (Microcyclus ulei).

\begin{tabular}{|c|c|c|c|c|c|c|c|c|c|c|c|c|}
\hline \multirow{3}{*}{$\begin{array}{l}\text { Clones } \\
\text { CNSAM } 7665\end{array}$} & \multicolumn{12}{|c|}{ Isolates } \\
\hline & \multicolumn{2}{|c|}{ MU_01 } & \multicolumn{2}{|c|}{ MU_02 } & \multicolumn{2}{|c|}{ MU_03 } & \multicolumn{2}{|c|}{ MU_04 } & \multicolumn{2}{|c|}{ MU_05 } & \multicolumn{2}{|c|}{ MU_06 } \\
\hline & & & & & & & & & $\begin{array}{l}9.00 \\
(0.0)\end{array}$ & $\mathrm{Aa}$ & $\begin{array}{c}7.83 \\
(0.29)\end{array}$ & $\mathrm{Ab}$ \\
\hline F 4542 & & & & & & & $\begin{array}{c}7.17 \\
(0.29)\end{array}$ & $\mathrm{Ba}$ & & & & \\
\hline Fx 2261 & $\begin{array}{c}8.50 \\
(0.71)\end{array}$ & $\mathrm{Aa}^{*}$ & $\begin{array}{c}8.67 \\
(0.29)\end{array}$ & $\mathrm{Aa}$ & $\begin{array}{c}8.50 \\
(0.71)\end{array}$ & Aa & $\begin{array}{c}7.25 \\
(0.35)\end{array}$ & $\mathrm{Bb}$ & $\begin{array}{c}5.67 \\
(0.29)\end{array}$ & $\mathrm{Cc}$ & $\begin{array}{c}7.00 \\
(0.00)\end{array}$ & $\mathrm{Bb}$ \\
\hline Fx 2804 & $\begin{array}{c}8.17 \\
(0.29)\end{array}$ & $\mathrm{Aa}$ & $\begin{array}{c}5.17 \\
(0.29)\end{array}$ & $\mathrm{Dc}$ & & & & & & & & \\
\hline Fx 3844 & & & & & & & $\begin{array}{c}7.00 \\
(0.00)\end{array}$ & $\mathrm{Ca}$ & $\begin{array}{c}5.83 \\
(0.29)\end{array}$ & $\mathrm{Dc}$ & $\begin{array}{c}6.33 \\
(0.29)\end{array}$ & $\mathrm{Cb}$ \\
\hline Fx 3864 & $\begin{array}{c}6.17 \\
(0.29)\end{array}$ & $\mathrm{Cb}$ & $\begin{array}{c}5.83 \\
(0.29)\end{array}$ & $\mathrm{Bc}$ & $\begin{array}{c}6.25 \\
(0.35)\end{array}$ & $\mathrm{Bb}$ & $\begin{array}{c}6.83 \\
(0.29)\end{array}$ & $\mathrm{Ca}$ & $\begin{array}{c}6.00 \\
(0.00)\end{array}$ & $\mathrm{Db}$ & $\begin{array}{c}6.17 \\
(0.29)\end{array}$ & $\mathrm{Db}$ \\
\hline Fx 3899 & & & $\begin{array}{c}6.00 \\
(0.50)\end{array}$ & $\mathrm{Bb}$ & $\begin{array}{c}6.00 \\
(0.00)\end{array}$ & $\mathrm{Bb}$ & $\begin{array}{c}6.83 \\
(0.29)\end{array}$ & $\mathrm{Ca}$ & $\begin{array}{c}6.13 \\
(0.25)\end{array}$ & $\mathrm{Db}$ & & \\
\hline Fx 3925 & & & $\begin{array}{c}5.67 \\
(0.29)\end{array}$ & $\mathrm{Cb}$ & $\begin{array}{c}5.50 \\
(0.00)\end{array}$ & $\mathrm{Cb}$ & $\begin{array}{c}6.50 \\
(0.00)\end{array}$ & $\mathrm{Ca}$ & $\begin{array}{c}5.67 \\
(0.29)\end{array}$ & $\mathrm{Cb}$ & & \\
\hline Fx 4098 & $\begin{array}{c}8.00 \\
(0.00)\end{array}$ & $\mathrm{Aa}$ & $\begin{array}{c}8.33 \\
(0.58)\end{array}$ & $\mathrm{Aa}$ & $\begin{array}{c}8.50 \\
(0.71)\end{array}$ & $\mathrm{Aa}$ & $\begin{array}{c}8.50 \\
(0.71)\end{array}$ & $\mathrm{Aa}$ & $\begin{array}{c}7.17 \\
(0.29)\end{array}$ & $\mathrm{Bb}$ & $\begin{array}{c}6.33 \\
(0.29)\end{array}$ & $\mathrm{Cc}$ \\
\hline Fx 985 & $\begin{array}{c}7.00 \\
(0.00)\end{array}$ & $\mathrm{Bb}$ & & & & & & & & & $\begin{array}{c}8.00 \\
(0.00)\end{array}$ & $\mathrm{Aa}$ \\
\hline GT 1 & $\begin{array}{c}5.17 \\
(0.29)\end{array}$ & $\mathrm{Db}$ & $\begin{array}{c}5.00 \\
(0.00)\end{array}$ & Dc & $\begin{array}{c}5.00 \\
(0.00)\end{array}$ & Dc & $\begin{array}{c}5.75 \\
(0.35)\end{array}$ & $\mathrm{Ea}$ & $\begin{array}{c}5.33 \\
(0.29)\end{array}$ & $\mathrm{Cb}$ & $\begin{array}{c}5.50 \\
(0.00)\end{array}$ & $\mathrm{Ea}$ \\
\hline IAN 2388 & $\begin{array}{c}8.00 \\
(0.50)\end{array}$ & $\mathrm{Aa}$ & & & & & & & $\begin{array}{c}7.67 \\
(0.76)\end{array}$ & $\mathrm{Ba}$ & $\begin{array}{c}7.83 \\
(0.29)\end{array}$ & $\mathrm{Aa}$ \\
\hline IAN 2909 & & & $\begin{array}{c}5.75 \\
(0.35)\end{array}$ & $\mathrm{Bb}$ & $\begin{array}{c}6.00 \\
(0.00)\end{array}$ & $\mathrm{Bb}$ & $\begin{array}{c}7.00 \\
(0.50)\end{array}$ & $\mathrm{Ca}$ & & & & \\
\hline IAN 3087 & & & $\begin{array}{c}6.25 \\
(0.35)\end{array}$ & $\mathrm{Ba}$ & $\begin{array}{c}6.00 \\
(0.00)\end{array}$ & $\mathrm{Ba}$ & $\begin{array}{c}5.83 \\
(0.29)\end{array}$ & $\mathrm{Eb}$ & $\begin{array}{c}5.33 \\
(0.29)\end{array}$ & $\mathrm{Cc}$ & & \\
\hline IAN 6158 & & & & & & & $\begin{array}{c}7.63 \\
(0.48)\end{array}$ & $\mathrm{Ba}$ & $\begin{array}{c}7.33 \\
(0.29)\end{array}$ & $\mathrm{Bb}$ & $\begin{array}{c}8.00 \\
(0.00)\end{array}$ & $\mathrm{Aa}$ \\
\hline IAN 6323 & $\begin{array}{c}7.00 \\
(0.00)\end{array}$ & $\mathrm{Ba}$ & $\begin{array}{c}5.67 \\
(0.29)\end{array}$ & $\mathrm{Cb}$ & $\begin{array}{c}5.75 \\
(0.35)\end{array}$ & $\mathrm{Cb}$ & $\begin{array}{c}6.00 \\
(0.50)\end{array}$ & $\mathrm{Db}$ & $\begin{array}{c}5.33 \\
(0.29)\end{array}$ & $\mathrm{Cc}$ & $\begin{array}{c}6.50 \\
(0.00)\end{array}$ & $\mathrm{Ca}$ \\
\hline IAN 7002 & & & $\begin{array}{c}5.83 \\
(0.29)\end{array}$ & $\mathrm{Bb}$ & $\begin{array}{c}6.00 \\
(0.00)\end{array}$ & $\mathrm{Ba}$ & $\begin{array}{c}6.33 \\
(0.29)\end{array}$ & $\mathrm{Da}$ & $\begin{array}{c}6.00 \\
(0.50)\end{array}$ & $\mathrm{Da}$ & & \\
\hline IAN 713 & $\begin{array}{c}7.00 \\
(0.00)\end{array}$ & $\mathrm{Ba}$ & & & & & $\begin{array}{c}7.00 \\
(0.00)\end{array}$ & $\mathrm{Ca}$ & $\begin{array}{c}6.67 \\
(0.29)\end{array}$ & $\mathrm{Cb}$ & $\begin{array}{c}6.00 \\
(0.00)\end{array}$ & Dc \\
\hline IAN 717 & & & $\begin{array}{c}5.17 \\
(0.29)\end{array}$ & $\mathrm{Db}$ & $\begin{array}{c}5.25 \\
(0.35)\end{array}$ & $\mathrm{Db}$ & $\begin{array}{c}5.88 \\
(0.48)\end{array}$ & $\mathrm{Ea}$ & $\begin{array}{c}5.50 \\
(0.41)\end{array}$ & $\mathrm{Ca}$ & & \\
\hline IAN 873 & $\begin{array}{c}5.25 \\
(0.35)\end{array}$ & $\mathrm{Db}$ & $\begin{array}{c}5.33 \\
(0.29)\end{array}$ & $\mathrm{Cb}$ & $\begin{array}{c}5.50 \\
(0.00)\end{array}$ & $\mathrm{Ca}$ & $\begin{array}{c}5.75 \\
(0.35)\end{array}$ & $\mathrm{Ea}$ & $\begin{array}{c}5.50 \\
(0.00)\end{array}$ & $\mathrm{Ca}$ & $\begin{array}{c}5.00 \\
(0.00)\end{array}$ & $\mathrm{Fc}$ \\
\hline MDF 180 & $\begin{array}{c}6.25 \\
(0.35)\end{array}$ & $\mathrm{Cb}$ & $\begin{array}{c}8.67 \\
(0.58)\end{array}$ & $\mathrm{Aa}$ & $\begin{array}{c}8.50 \\
(0.71)\end{array}$ & $\mathrm{Aa}$ & & & $\begin{array}{c}6.00 \\
(0.41)\end{array}$ & Dc & $\begin{array}{c}6.83 \\
(0.29)\end{array}$ & $\mathrm{Bb}$ \\
\hline PB 86 & $\begin{array}{c}5.00 \\
(0.00)\end{array}$ & $\mathrm{Db}$ & $\begin{array}{c}5.17 \\
(0.29)\end{array}$ & $\mathrm{Da}$ & $\begin{array}{c}5.00 \\
(0.00)\end{array}$ & $\mathrm{Da}$ & $\begin{array}{c}5.25 \\
(0.35)\end{array}$ & $\mathrm{Fa}$ & $\begin{array}{c}5.33 \\
(0.29)\end{array}$ & $\mathrm{Ca}$ & $\begin{array}{c}5.33 \\
(0.29)\end{array}$ & $\mathrm{Ea}$ \\
\hline RRIM 600 & $\begin{array}{c}5.17 \\
(0.29)\end{array}$ & $\mathrm{Da}$ & $\begin{array}{c}5.33 \\
(0.58)\end{array}$ & $\mathrm{Ca}$ & $\begin{array}{c}5.25 \\
(0.35)\end{array}$ & $\mathrm{Da}$ & $\begin{array}{c}5.50 \\
(0.00)\end{array}$ & $\mathrm{Ea}$ & $\begin{array}{c}5.50 \\
(0.50)\end{array}$ & $\mathrm{Ca}$ & $\begin{array}{c}5.17 \\
(0.29)\end{array}$ & $\mathrm{Fa}$ \\
\hline
\end{tabular}

*Means followed by the same uppercase letter in the column and lowercase letter on the line do not differ statistically according to LSM test (p<0.05). 




Figure 1. Horizontal resistance (HR) and vertical resistance (VR) of rubber tree clones to Microcyclus ulei isolates considering the monocyclic parameter of lesion diameter $\left(\mathrm{mm}^{2}\right)$.



Figure 2. Horizontal resistance (HR) and vertical resistance (VR) of rubber tree clones to isolates of Microcyclus ulei considering the monocyclic parameter of latent period (days).

The evaluated infection process parameters (latent period and lesion diameter) are applicable to resistance quantification for Hevea sp. $x$ M. ulei pathosystem.

Latent period slightly varied among clones.

Lesion diameter widely varied among clones and was a discriminating parameter for horizontal resistance and vertical resistance.
The rubber tree clones Fx 3864, Fx 3844, Fx 3899, GT 1, IAN 713, IAN 873, IAN 6323, IAN 7002, PB 86 and RRIM 600 are most suscetible to SALB.

The clones Fx 985, Fx 4098, IAN 2388, IAN 2909 and IAN 6158 have greater resistance to South American leaf blight. 


\section{REFERENCES}

1. Bergamin Filho, A. Alternativas para o controle do mal das folhas da seringueira: uma revisão. Summa Phytopathologica, Piracicaba, v.8, n.3-4, p.65-74, 1982 .

2. Bergamin Filho, A; Amorim, L. Epidemiologia comparativa entre os patossistemas temperado e tropical: conseqüências para a resistência a fungicidas. Fitopatologia Brasileira, Brasília, v.26, n.2, p.119-127, 2001.

3. Bevenuto, J.A.Z; Passos, J.R.S, Furtado, E.L. Microcyclus ulei races in Brazil. Summa Phytopathol, Botucatu, v.43, n.4, p.326-336, 2017.

4. Diggle, P.J., Heagerty, P.J., Liang, K.Y. And Zeger, S.L. Analysis of Longitudinal Data. $2^{\text {nd }}$ ed. Oxford: Oxford University Press, 2002. 379p.

5. Ferreira, F.A. Patologia Florestal: Principais doenças no Brasil. Viçosa: SIF, 1989. 570p.

6. Furtado, E.L.; Menten, J.O.M.; Passos, J.R. Intensidade do mal das folhas em plantas jovens e adultas de seis clones de seringueira na região do Vale do Ribeira. Tropical Plant Pathological, Brasília, v.33, n.2, p.130-137, 2008.

7. Furtado, E.L.; Gasparotto, L.; Pereira, J.C.R. Doenças da seringueira. In: Amorim, L.; Rezende, J.A.M.; Bergamin Filho, A.; Camargo, L.E.A. Manual de Fitopatologia: doenças de plantas cultivadas. $5^{\text {th }}$ ed. SP: Agronômica Ceres, v.2, p.647-656, 2016.

8. Gasparotto, L.; Pereira, J.C.R. Doenças da seringueira no Brasil. $2^{\text {nd }}$ ed. DF: Embrapa. 2012. 255p.

9. Gonçalves, P.S.; Paiva, J.R.; Souza, R.A. Retrospectiva e atualidade no melhoramento genético da seringueira (Hevea spp.) no Brasil e em países asiáticos. Manaus: EMBRAPA/CNPSD. 1983. 69p.

10. Gonçalves, P.S.; Cardoso, M.; Ortolani, A.A. Origem, variabilidade e domesticação da Hevea: uma revisão. Pesquisa Agropecuária Brasileira, Brasília, v.25, n.2, p.135-156, 1990.

11. IBGE. Produção Agrícola Municipal 2019: culturas temporárias e permanentes. IBGE, Rio de Janeiro, 2020. Available in: <https:/www.ibge.gov. br/explica/producao-agropecuaria/borracha-latex-coagulado/br $>$. Accessed on: 5 may. 2021.

12. Hallé, F.; Oldeman, R.A.A.; Tomlinson, P.B. Tropical trees and forests: An Architectural Analysis. New York: Springer-Verlag Berlin Heidelberg. 1978. 444p.
13. Junqueira, N.T.V.; Chaves, G.M.; Zambolim, L.; Gasparotto, L.; Alfenas, A.C. Variabilidade fisiológica de Microcyclus ulei. Fitopatologia Brasileira, Brasília, v.11, p.823-833, 1986.

14. MDIC. Ministério do Desenvolvimento, Indústria e Comércio Exterior. Balança comercial brasileira: janeiro-dezembro de 2017, Available at: $<$ http://www.mdic.gov.br/comercio-exterior/estatisticas-de-comercio-exterior/balanca-comercial-brasileira-mensal-2>. Accessed on: 26 jun. 2018.

15. Menten, J.O.M. Evitação: forma de defesa das plantas contra patógenos que deve ser melhor compreendida e explorada. Summa Phytopathologica, Jaguariuna, v.16, n.2, p.77-83, 1990.

16. Nelder, J.A; Wedderburn, R.W. Generalized linear models. Journal of the Royal Statistical Society Series A, London, v.135, n.3, p.370-384, 1972

17. Paiva, J.R.; Kalil Filho, A.N. Melhoramento genético de seringueira. Informe Agropecuário, Belo Horizonte, v.11, n.121 p.52-58, 1985.

18. Parleviliet, J.E. Plant pathosystems: an attempt to elucidate horizontal resistance. Euphytica, Dordrecht, v.26, n.3, p.553-556, 1977.

19. Peralta, A.M.; Furtado, E.L.; Amorim, L.; Menten, J.O.M.; Bergamin Filho, A. Melhoramento para resistência ao mal das folhas da seringueira: revisão. Summa Phytopathologica, Jaguariuna, v.16, n. 3-4, p.214-224, 1990.

20. Robinson, R.A. New concepts in breeding for disease resistance. Annual Review of Phytopathology, Palo Alto, v.18, n.1, p.189-210, 1980.

21. Sambugaro, R.; Furtado, E.L.; Rodella, R.A.; Mattos, C.R.R. Anatomia foliar de seringueira (Hevea spp.) e desenvolvimento da infecção por Microcyclus ulei. Summa Phytopathologica, Botucatu, v.30, n.1, p.51-56, 2004.

22. Soares, N.S., Silva, M.L., Valverde, S.R., Alves, R.R., Santos, F. L. Análise Econômica da demanda brasileira de importação de borracha natural, de 1964 a 2005. Revista Árvore, Viçosa, v.32, n.6, p.1133-1142, 2008.

23. Vanderplank, J.E. Plant diseases: epidemics and control. New York, Academic Press, 1963. 349p.

24. Vanderplank, J.E. Genetic and molecular basis of plant pathogenesis. Berlin Heidelberg, Springer-Verlag, 1978. 170p.

25. Westfall, P. H., Tobias, R. D., Rom, D., Wolfinger, R. D., and Hochberg, Y. Multiple Comparisons and Multiple Tests Using the SAS System. Cary, NC: SAS Institute Inc. 1999. 416p. 